\title{
PENGARUH PENGGUNAAN SIMULASI BINARY TREE BERBASIS CAI TERHADAP MOTIVASI DAN HASIL BELAJAR MATEMATIKA DISKRIT MAHASISWA JURUSAN PTI UNDIKSHA
}

\author{
Ketut Agustini ${ }^{1}$, Dessy Seri Wahyuni ${ }^{2}$ \\ 1,2 Jurusan Pendidikan Teknik Informatika, Falultas Teknik dan Kejuruan \\ Universitas Pendidikan Ganesha, \\ Singaraja, Indonesia \\ e-mail : Eghee2006@Gmail.com, dsy.wahyuni@gmail.com
}

\begin{abstract}
Abstrak
Tujuan dari penelitian ini adalah memanfaatkan produk yang dihasilkan melalui pengujian secara eksperimen, untuk mengetahui efektifitas produk terhadap tingkat penguasaan konsep mahasiswa jurusan Pendidikan Teknik Informatika Undiksha. Rancangan penelitian yang digunakan adalah quasi eksperimen menggunakan desain post test dengan kelompok eksperimen dan kontrol yang tidak diacak. Hasil penelitian diperoleh bahwa respon mahasiswa terhadap penggunaan sistem simulasi binary tree berbasis CAI dalam perkuliahan matematika diskrit adalah positif dan Motivasi belajar mahasiswa masuk dalam kategori tinggi. Pengujian rumusan hipotesis yang dilakukan dengan uji t (student) diperoleh hasil bahwa terdapat perbedaan yang signifikan antara hasil belajar mahasiswa yang dibelajarkan menggunakan Media Simulasi binary tree berbasis CAI dengan mahasiswa yang dibelajarkan tanpa menggunakan Media Simulasi binary tree berbasis CAI. Hal ini menunjukkan bahwa simulasi binary tree berbasis CAl merupakan media yang efektif digunakan untuk meningkatkan penguasaan konsep mahasiswa dalam perkuliahan matematika diskrit di jurusan Pendidikan Teknik Informatika Undiksha Singaraja.
\end{abstract}

Kata-kata kunci : Simulasi Binary tree berbasis CAl, Pembelajaran Matematika diskrit, respon, hasil belajar, motivasi.

\begin{abstract}
The purpose of this study was to use the products produced through experimental testing, to determine the effectiveness of the product of the level of mastery of concepts students majoring in Information Technology Education Undiksha. The design of the study is a quasi experimental design using post test with experimental and control groups were not randomized. The result showed that the response of students to the use of binary tree based system simulation CAl in discrete math course was positively and student learning motivation in the high category. Formulation of hypothesis testing performed by $t$ test (student) result that there are significant differences between the learning outcomes of students who learn to use the Media Simulation-based binary tree CAI with students studying without using Media Simulation-based binary tree CAI. This shows that the simulation-based CAI binary tree is an effective medium used to improve student mastery of concepts in discrete mathematics lectures in the Department of Informatics Engineering Education Undiksha Singaraja.
\end{abstract}

Key words: Simulation-based CAI Binary tree, Discrete Mathematics Learning, responsiveness, learning outcomes, motivation. 


\section{PENDAHULUAN}

Sistem pendidikan dewasa ini telah mengalami kemajuan yang sangat pesat. Berbagai cara telah dikenalkan serta di gunakan dalam proses pembelajaran dengan harapan pengajaran akan lebih berkesan dan pembelajaran bagi siswa akan lebih bermakna. Sejak beberapa tahun belakangan ini teknologi informasi dan komunikasi telah banyak digunakan dalam proses belajar mengajar, dengan satu tujuan mutu pendidikan akan selangkah lebih maju seiring dengan kemajuan teknologi.

Dalam rangka meningkatkan sumber daya manusia yang berkualitas diperlukan strategi pembelajaran yang diharapkan mampu memperbaiki sistem pendidikan yang telah berlangsung selama ini. Salah satu tolok ukur keberhasilan pendidik adalah bila dalam pembelajaran mencapai hasil yang optimal. Keberhasilan ini sangat dipengaruhi oleh kemampuan dan kreatifitas pendidik untuk mengelola proses belajar mengajar. Komunikasi dua arah atau multi arah secara timbal balik sangat diharapkan dalam proses belajar mengajar, demi tercapainya interaksi belajar yang optimal, yang pada akhirnya bermuara kepada pencapaian sasaran hasil belajar yang maksimal. Untuk mencapai kondisi yang demikian maka perlu adanya fasilitator yaitu dosen/guru, yang memiliki kemampuan untuk menciptakan situasi belajar yang melibatkan siswa secara aktif dan juga terpusat pada siswa (student center learning) dengan mengembangkan kegiatan pembelajaran yang inovatif untuk meningkatkan motivasi siswa. Pembelajaran inovatif dapat dilakukan dengan mengembangkan perangkat, menggunakan media pembelajaran, mengembangkan sumber belajar, memanfaatkan ICT (information and communication technology) dalam pembelajaran, dan lain sebagainya.

Sistem pembelajaran yang selama ini dilakukan yaitu sistem pembelajaran konvensional (faculty teaching), kental dengan suasana instruksional dan dirasa kurang sesuai dengan dinamika perkembangan ilmu pengetahuan dan teknologi yang demikian pesat. Lebih dari itu kewajiban pendidikan dituntut untuk juga memasukkan nilai-nilai moral, budi pekerti luhur, kreatifitas, kemandirian dan kepemimpinan, yang sangat sulit dilakukan dalam sistem pembelajaran yang konvensional. Sistem pembelajaran konvensional kurang fleksibel dalam mengakomodasi perkembangan materi kompetensi karena dosen harus intensif menyesuaikan materi pelajaran dengan perkembangan teknologi terbaru. Adalah Kurang bijaksana jika perkembangan teknologi jauh lebih cepat dibanding dengan kemampuan dosen dalam menyesuaikan materi kompetensi dengan perkembangan tersebut, oleh karenanya dapat dipastikan lulusan akan kurang memiliki penguasaan pengetahuan/teknologi yang terbaru (Sudrajat,2009). Mata kuliah matematika diskrit merupakan mata kuliah wajib di Jurusan Pendidikan Teknik Informatika, yang bertujuan untuk memfasilitasi mahasiswa untuk membangun profesionalisme dan wawasan yang luas dalam cakupan matematika diskrit. Hal ini sesuai dengan standar kompetensi yang termuat dalam kurikulum, yaitu: "Mahasiswa mampu mengetahui secara teoretik, mengkaji dan mengaplikasikan konsepkonsep dan prinsip-prinsip matematika diskrit serta mengkonstruksikan konsep matematis komputer digital yang bekerja dalam obyek-obyek diskrit " (Katalog Jurusan Pendidikan TI, 2010).

Bekal profesionalisme dan wawasan yang luas bagi mahasiswa dalam cakupan matematika diskrit tersebut direpresentasikan oleh pokok-pokok bahasan yang menjadi substansi kurikulum. Pokok-pokok bahasan tersebut adalah: "terminologi graf, penelusuran dan optimisasi dalam graf, pohon (tree), pohon biner (binarytree) dan aplikasi pohon biner" (Katalog Jurusan Pendidikan TI, 2010). Dengan sebaran dimensi konseptual yang lengkap tersebut, idealnya setelah perkuliahan mahasiswa diharapkan mampu 
mengetahui secara teoretik, mengkaji dan mengaplikasikan konsep-konsep yang memadai termasuk dalam pokok bahasan yang menjadi substansi kurikulum. Kompetensi mengetahui, memahami serta kemampuan mengkonstruksikan yang telah dimiliki mahasiswa dapat tercermin dari kinerja mahasiswa dalam menjalani proses perkuliahan yang berhasil diamati dan nilai akhir semester yang diperolehnya selama ini. Namun, harapan tersebut tampak belum tercapai secara optimal. Hal ini terbukti dari berbagai masalah yang ditemukan. Hasil pengamatan terhadap proses perkuliahan dan kompetensi pemahaman/penguasaan konsep serta kemampuan mengkonstruksi mahasiswa, terkait dengan kinerja mereka dalam menampilkan kompetensi tersebut di dalam cakupan kurikulum matematika diskrit, teridentifikasi masalah-masalahnya sebagai berikut.

Pertama, Hasil Identifiksi peneliti selama ini melihat bahwa kemampuan mahasiswa melakukan investigasi utamanya dalam menelusuri berbagai sumber dan mencemati sumber-sumber tersebut terkait dengan kebutuhan mereka akan perkuliahan matematika diskrit tampak relatif rendah kualitasnya. Fakta ini terbukti ketika mahasiswa hadir pada perkuliahan perdana pada tahun-tahun sebelumnya dalam pembelajaran matematika diskrit, hampir semua mahasiswa belum siap dengan buku yang seharusnya mereka gunakan dan materi-materi apa saja yang ada dalam buku tersebut yang seharusnya mereka investigasi untuk dijadikan pijakan perkuliahan. Ketika mahasiswa ditanya mengenai tujuan perkuliahan matematika diskrit, hampir $100 \%$ mahasiswa tidak berani merespon. Demikian pula, ketika mahasiwa ditanya satu persatu mengenai konsepkonsep dasar matematika diskrit, 95\% mahasiswa tidak mampu menunjukkan respon yang benar. Padahal konsep-konsep dasar matematika diskrit sebagian besar telah diperoleh mahasiswa ketika mereka memprogramkan perkuliahan matematika dasar dan kalkulus di semester awal, serta seharusnya mahasiswa mempunyai inisiatif mencari melalui internet mengingat sebagai mahasiswa yang berada dibawah jurusan dengan domain keilmuan Informatika/komputer. Hal ini mengindikasikan rendahnya motivasi dan inisiatif mahasiswa terhadap konsepkonsep dasar matematika diskrit sebagai akibat rendahnya kemampuan mahasiswa untuk melakukan investigasi baik secara individual maupun kelompok. Rendahnya motivasi tersebut berimplikasi terhadap rendahnya kompetensi mahasiswa dalam mengkonstruksi penguasaan dan pemecahan masalah yang akhirnya bermuara pada rendahnya kemampuan mahasiswa mengkonstruksi kompetensi pemecahan masalah seputar konsepkonsep matematika diskrit.

Kedua, dalam pembelajaran Matematika Diskrit, proses pembelajaran banyak yang bersifat abstrak dan cukup kompleks, juga karakter materi matematika yang kaku (rigid) karena sangat bersifat kuantitatif (numeric). Konsep matematika diskrit aplikasinya banyak digunakan pada mata kuliah selanjutnya, seperti pada mata kuliah algoritma dan struktur data, Jaringan komputer, sistem operasi, otomata dan teori bahasa formal, teknik kompilasi, dsb. Ini terlihat dari sekian soal matematika diskrit yang diberikan pada saat ujian tengah dan akhir semester, jawaban yang diberikan banyak yang tidak memuaskan, bahkan ada yang tidak menjawab sama sekali sehingga kompetensi dalam memecahkan permasalahan yang diberikan tampak rendah kualitasnya.

Ketiga, dilihat dari nilai mahasiswa pada tiga tahun sebelumnya, tampak bahwa sebaran nilai matematika diskrit belum optimal.

Permasalah yang diuraikan tersebut mengindikasikan bahwa upaya mahasiswa untuk menginternalisasi dan mengaplikasikan konsep-konsep yang tersurat dan tersirat pada Mata Kuliah Matematika diskrit terkesan abstrak dan cukup kompleks memicu tingkat kesulitan 
yang cukup tinggi bagi mahasiswa untuk dapat menguasainya dengan baik sehingga berimplikasi terhadap hasil belajar. Disamping itu, kurangnya keterampilan dosen dalam memanfaatkan media ataupun simulasi pembelajaran, membuat fokus pembelajaran hanya terpusat pada dosen (teacher centered). Dosen pengajar mata kuliah masih sulit untuk menemukan konsep pembelajaran yang lebih nyata untuk dapat membantu mahasiswa.

Kehadiran aplikasi CAI dapat memfasilitasi proses pembelajaran. Teknologi CAI bisa dimanfaatkan untuk merefleksikan proses kognitif yang digunakan untuk mengakuisisi kemampuan siswa yang berhubungan dengan matematika, ilmu pengetahuan dan teknik. Aplikasi CAI ditujukan untuk memanfaatkan pengetahuan dan level pengalaman dari siswa sebagai pengguna yang spesifik. Hasil penelitian di US menyatakan bahwa proses belajar mengajar yang dibantu alat peraga meningkatkan efisiensi sebesar $47 \%$, sedangkan dibantu ICT dapat meningkatkan efisiensi sebesar 93\%. (Saroso,2009). Disamping itu, menurut seorang peneliti dari Turkey (Mustafa Bacak et all, 2011) dalam jurnal penelitiannya mengatakan bahwa

"Computer-based learning has the potential to facilitate development of students decision-making and problemsolving skills, data-processing skills, and communication capabilities. By using computer, students can gain access to expansive knowledge links and broaden their exposure to diverse people and perspectives"

Averill M. Law menuliskan bahwa : "..., most real-world systems are too complex to allow realistic models to be evaluated analytically, and these models must be studied by means of simulation." (Law Averill M., dalam Windu Antara,2009). Simulasi adalah salah satu teknik yang sangat luas digunakan dalam bidang riset operasional dan ilmu manajemen. Lebih lanjut dalam bukunya, Averill M. Law memberikan definisi global tentang simulasi sebagai berikut : "In a simulation we use a computer to evaluate a model numerically, and data are gathered in order to estimate the desired true characteristics of the model".

Pada penelitian sebelumnya telah dikembangkan sebuah Media Simulasi binary tree berbasis CAI yang telah melalui beberapa tahapan uji coba seperti uji coba terbatas kelompok kecil, uji ahli isi, desain dan media, namun belum sampai kepada tahapan uji coba kelompok besar. Untuk mengetahui efektifitas media tersebut serta pengaruhnya terhadap penguasaan konsep dilihat dari hasil belajar matematika diskrit, maka pada penelitian ini akan dilakukan pengujian secara eksperimen mengenai pengaruh media simulasi binary tree berbasis CAl terhadap motivasi dan hasil belajar matematika diskrit mahasiswa Jurusan Pendidikan Teknik Informatika Undiksha terhadap penggunaan media simulasi tersebut. Rumusan masalah yang akan dicarikan solusinya adalah Bagaimana pengaruh penggunaan media simulasi binary tree berbasis CAl terhadap hasil belajar matematika Diskrit mahasiswa PTI Undiksha? Bagaimana motivasi belajar mahasiswa PTI Undiksha setelah menggunakan media simulasi binary tree berbasis CAI dalam pembelajaran Matematika Diskrit? Serta Bagaimana respon mahasiswa Jurusan PTI Undiksha terhadap penggunaan media simulasi binary tree berbasis $C A I$ pada pembelajaran Matematika Diskrit?

Hasil penelitian ini diharapkan dapat memberikan sumbangan yang positif terhadap pengembangan pembelajaran di bidang komputer dan informatika. Manfaat yang dapat diambil secara khusus adalah (i) Manfaat bagi dosen dan mahasiswa bidang ilmu informatika, Pengembangan dan penggunaan simulasi binary tree berbasis CAI untuk pembelajaran Matematika diskrit ini diharapkan dapat meningkatkan motivasi belajar mahasiswa. Alternatif media pembelajaran ini diharapkan dapat 
membantu dan mempermudah mahasiswa untuk melaksanakan proses pembelajaran yang lebih baik karena media ini memadukan komponen isi (content), pedagogi, dan antarmuka (interface), serta mampu meningkatkan pemahaman dan penguasaan konsep dalam Mata Kuliah Matematika Diskrit. (ii) Manfaat bagi Undiksha, Peningkatan kualitas pembelajaran yang didukung dengan pemanfaatan ICT yang dilakukan dalam penelitian ini diharapkan dapat memberikan nilai tambah yang lebih luas bagi Undiksha sebagai sebuah lembaga pendidikan penghasil guru yang berkualitas. Penelitian ini diharapkan mampu memicu inspirasi lebih lanjut untuk mendayagunakan teknologi dalam memajukan pendidikan bangsa, dan juga turut serta untuk menumbuhkan dan meningkatkan produktivitas ilmiah para dosen Undiksha. (iii) Manfaat bagi Peneliti, Penelitian ini merupakan bagian dari proses pembelajaran pengejawantahan ide dan pemikiran ke dalam bentuk tulisan ilmiah yang berkualitas, yang berguna di masa mendatang untuk penciptaan karya-karya ilmiah selanjutnya. Peneliti diharapkan mampu untuk turut berperan serta secara aktif dalam menumbuhkembangkan budaya meneliti, khususnya dalam mencari solusi terhadap permasalahan pembelajaran di Undiksha dan turut mengembangkan Subject-Specific Pedagogy (SSP).

Menurut (Smith Adrian, 1997) Model komputer dalam pendidikan bisa dibagi menjadi tiga kategori yaitu :

\section{Pure computer software \\ 2. Integrated courseware \\ 3. Virtual reality (Smith Adrian, 1997)}

Untuk kategori pure computer software, terdapat dua jenis model yaitu:

1. Emulation

2. Simulation

Definisi yang diberikan untuk membedakan kedua model tersebut adalah sebagai berikut:
"Emulations concentrate more on teaching principles, rather than the absolute response to a given stimulus. They have often a high degree of realism but lack quantitative accuracy." (Smith Adrian, 1997)

Sedangkan definisi simulation adalah: "Simulations aim to depict scenarios that are as close to the real-life situation as possible, with quantitatively correct data." (Smith Adrian, 1997)

Berbagai aplikasi CAI telah banyak dihasilkan dari beberapa penelitian, terutama untuk siswa sekolah menengah. Bentuk-bentuk aplikasi CAI ini sangat bervariasi, mulai dari materi mikroelektronik sampai simulasi fotosintesis. Beberapa bentuk aplikasi CAI yang dapat ditemukan saat ini misalnya TS-24 Telescope Simulator (Mumford, 1992), PROJ1D (Redish \& Wilson, 1993), Scholastic (Nova series), ABC Interactive's AIDS, Human Sexuality, Tobacco and Drugs \& Substance Abuse, Race to Save the Planet, Animal Pathfinders, dan Mystery Fossil (Matray \& Proulx, 1995). Sebuah aplikasi CAI di bidang kimia didesain untuk menggantikan laboratorium tradisional. CAI didesain sedemikian sehingga guru bisa memasukkan instruksi-instruksi ke dalam program, dan aplikasi akan berubah menurut instruksi tersebut. Program akan mensimulasikan peralatan laboratorium dan membimbing siswa untuk menyelesaikan prosedur praktikum (De La Cuetara \& Lamba, 1995).

Aplikasi CAl sangat efektif untuk diterapkan. Salah satu alasan utamanya adalah karena siswa lebih senang belajar pada lingkungan yang ditawarkan oleh sebuah komputer. Aplikasi CAI dewasa ini jauh lebih userfriendly dan semakin menarik dibandingkan pendahulu-pendahulunya, seperti yang dituliskan oleh Gifford: "These technologies move us light years beyond the tedious drill that early educational software promoted, and allow highly engaging activities like multimedia simulation" (Gifford, 1993). Saat ini siswa bisa bekerja di level manapun yang 
mereka inginkan. Hal ini memicu kepercayaan diri bagi mereka karena hal tersebut dapat memberikan kontrol atas diri sendiri mengenai hal-hal yang mereka pelajari. Menurut Matray \& Proulx, "The computer has allowed the student to become a more active participant in his/her education..." (Matray \& Proulx, 1995).

Berbeda dengan metode

pengajaran tradisional, CAI memaksa siswa untuk tetap fokus pada sebuah topik yang sedang dipelajarinya. Aplikasi CAI menjamin siswa untuk tetap memperhatikan dan mengerti pelajaran dengan cara menguji mereka secara terus-menerus melalui informasi yang diberikan oleh aplikasi. Hal ini sangat membantu untuk siswa yang memiliki kesulitan dalam pembelajaran. Hasil penelitian Malone \& Reiland menemukan bahwa dengan penggunaan CAl, siswa menjadi sangat inventif dan sangat menikmati pelajaran, meskipun untuk topik yang sulit, seperti pernyataan Malone \& Reiland :

"The use of these methods saved (the teachers) considerable class time and, best of all, post-test results show that the students internalized Newton's third law and retained it till (the end of the school year" (Malone \& Reiland, 1995).

Aplikasi CAI juga sangat efektif karena berhubungan dengan contoh-contoh yang lebih praktis dibandingkan contoh-contoh yang ditemukan pada buku-buku teks pelajaran, dan memberikan berbagai pengalaman virtual secara langsung kepada siswa. Konsep group work dewasa ini juga mulai ditemukan pada aplikasi CAI, dengan tujuan agar siswa bisa mengkolaborasikan ide dan pemikirannya dengan siswa lain selama pemebelajaran dengan CAI. Teknologi CAl telah membawa perubahan drastis terhadap kelas-kelas atau laboratorium konvesional. Guru dan siswa diharapkan mampu mengubah peranannya dalam pendidikan. Dengan teknologi CAI, peran guru telah berubah dari sumber pengetahuan menjadi pembimbing personal bagi siswa. Siswa yang pasif akan menjadi lebih aktif di kelas, "CAl has encouraged students to "explore more and memorize less." (Matray \& Proulx, 1995).

Satu hal yang perlu diperhatikan adalah CAl tidak didesain untuk menggantikan guru, tetapi untuk mempertajam metode pengajaran yang ada saat ini, seperti yang dinyatakan oleh Peck \& Dorricott:

"Some things only teachers can do. Teachers can build strong, productive relationships with students. Technologies can't. Teachers can motivate students to love learning. Technologies can't. Teachers can identify and meet students' emotional needs. Technologies can't. Technologybased solutions in education can, and must, free the teacher to do the important work that requires human interaction, continuous evaluation, and improvement of the learning environment." (Peck \& Dorricott, 1994)

\section{METODE}

Metode yang digunakan dalam penelitian ini adalah metode penelitian eksperimen dengan rancangan quasi eksperimen menggunakan desain post test dengan kelompok eksperimen dan kontrol yang tidak diacak. Dari dua kelas yang ada, dipilih secara random satu kelas sebagai kelas eksperimen dan kelas lain sebagai kelas kontrol. Kelompok eksperimen diberi perlakuan yakni pembelajaran di kelas menggunakan media simulasi binary tree berbasis CAI, sedangkan pada kelompok kontrol pembelajarannya dilakukan secara konvensional.

Uji coba lapangan untuk menguji kebenaran dari hipotesis penelitian, dilakukan melalui uji eksperimen ke mahasiswa Jurusan Pendidikan Teknik Informatika, Universitas Pendidikan Ganesha, Singaraja, yang mengambil mata kuliah Matematika Diskrit. Perangkat lunak yang telah dihasilkan dan diuji melalui tahapan pengembangan, selanjutnya diujikan dalam pembelajaran di kelas untuk melihat pengaruhnya pada tingkat 
penguasaan konsep matematika diskrit, motivasi belajar mahasiswa dan respons mahasiswa terhadap penggunaan media.

Penelitian ini dilakukan di Jurusan Pendidikan Teknik Informatika, Universitas Pendidikan Ganesha, Singaraja. Yang akan menjadi sampel/subjek dalam penelitian ini adalah mahasiswa Jurusan Pendidikan Teknik Informatika, Universitas Pendidikan Ganesha, yang mengambil Mata Kuliah Matematika Diskrit pada semester II. Yang menjadi objek dalam penelititian ini adalah penggunaan media simulasi binary tree berbasis $\mathrm{CAl}$, motivasi belajar mahasiswa dan penguasaan konsep mahasiswa yang dilihat dari hasil belajar matematika diskrit mahasiswa.

Dari dua kelas yang ada, dipilih secara random satu kelas sebagai kelas eksperimen dan satu kelas lain sebagai kelas kontrol, sehingga tergolong dalam pelaksanaan eksperimen kuasi (quasi experimental designs). Teknik pengambilan sampel dilakukan mengingat pemilihan mahasiswa untuk masuk ke kelas eksperimen atau kelas kontrol secara random murni (eksperimen sungguhan/true experimental designs) tidak memungkinkan untuk dilakukan lagi karena secara administratif di Undiksha, masing-masing mahasiswa telah terdaftar sebagai mahasiswa kelas tertentu untuk satu mata kuliah tertentu, sesuai dengan jadwal perkuliahan dan ruang kuliah yang telah ditetapkan di awal pendaftaran mata kuliah.

Terdapat tiga bentuk penilaian yang

dilakukan terhadap mahasiswa untuk mengukur penguasaan konsep dalam perkuliahan Matematika Diskrit, yaitu penilaian tugas, penilaian quiz, dan penilaian ujian. Penilaian tugas secara tertulis, bisa berupa tugas individual atau tugas berkelompok. Penilaian quiz diberikan secara spontan dan secara individual kepada masing-masing mahasiswa, untuk mengukur kesiapan mahasiswa untuk mengikuti materi perkuliahan selanjutnya, sesuai dengan materi perkuliahan yang telah diberikan pada pertemuan-pertemuan sebelumnya. Validitas isi soal ujian terlebih dahulu diuji 2 orang dosen dari Jurusan Pendidikan Teknik Informatika Undiksha. Validitas isi diuji agar isi soal ujian sesuai dengan tujuan pembelajaran dan materi yang diberikan. Masing-masing penilai diminta memberi saran atau komentar untuk setiap butir soal yang berbeda. Angket motivasi dan angket respons mahasiswa validitasnya diuji dengan expert judgement dengan menggunakan skala likert 5, Motivasi mahasiswa dan respons mahasiswa diukur setelah pelaksanaan pembelajaran.

Seperti yang telah dijelaskan sebelumnya, dari dua kelas yang ada, dipilih secara random satu kelas sebagai kelas eksperimen dan dua kelas lain sebagai kelas kontrol. Kelompok eksperimen diberi perlakuan yakni pembelajaran di kelas menggunakan simulasi berbasis CAI, sedangkan pada kelompok kontrol pembelajarannya dilakukan secara konvensional. Capaian prestasi masingmasing kelompok selanjutnya dianalisis menggunakan uji-t dengan membandingkan perbedaan mean dari kedua kelompok. Formulasi uji-t yang digunakan adalah sebagai berikut.

$$
t=\frac{\overline{X_{1}}-\overline{X_{2}}}{\sqrt{\frac{S_{1}^{2}}{n_{1}}+\frac{S_{2}^{2}}{n_{2}}}}
$$

dimana :

$$
\begin{aligned}
& \overline{x_{1}}-\frac{t}{x_{2}} \quad \text { : rasio- } t \\
& \overline{X_{1}}-\overline{X_{2}} \quad \text { : perbedaan antara Mean } \\
& \text { kelompok } 1 \text { dan Mean } \\
& \text { kelompok } 2 \text { yang diamati } \\
& S_{1}^{2} \text { dan } S_{2}^{2} \quad \text { : varian antara dua Mean } \\
& n_{1} \quad \text { : jumlah individu dalam } \\
& \text { kelompok } 1 \\
& n_{2} \quad \text { : jumlah individu dalam } \\
& \text { kelompok } 2
\end{aligned}
$$

(Sugiyono,2010)

Nilai uji-t hasil kalkulasi selanjutnya dibandingkan dengan nilai t-tabel dengan taraf signifikansi 95\% (taraf nyata 0,05 ) (Sudjana, 1996). Disamping itu, semua data 
yang diperoleh dari pengukuran penguasaan konsep mahasiswa, dievaluasi menggunakan criterion referenced test, menggunakan pemetaan prosentase yang menerangkan hasil belajar dan tingkat penguasaan kosep perkuliahan. Nilai-nilai tersebut diolah dari skor 100 dengan standar patokan mengikuti buku pedoman studi (Departemen Pendidikan Nasional, Universitas Pendidikan Ganesha, 2009) dengan rincian dengan perincian sebagai berikut :

Tabel 1. Rentangan Skor Nilai Akhir

\begin{tabular}{|c|c|c|}
\hline No & Rentangan Skor & Nilai Akhir \\
\hline 1 & $85-100$ & A \\
\hline 2 & $70-84$ & B \\
\hline 3 & $55-69$ & C \\
\hline 4 & $40-54$ & D \\
\hline 5 & $0-39$ & E \\
\hline
\end{tabular}

Data motivasi dan respons mahasiswa dianalisis dengan menggunakan statistik deskriptif, dan penyimpulannya didasarkan atas Mean Ideal $\left(\mathrm{M}_{\mathrm{i}}\right)$ dan simpangan baku ideal $\left(\mathrm{S}_{\mathrm{i}}\right)$. Konversi tingkat motivasi belajar mahasiswa dapat dilihat pada Tabel 2 berikut ini :

Tabel 2. Tabel Pedoman Konversi Tingkat Motivasi Belajar Mahasiswa

\begin{tabular}{|c|c|}
\hline \multicolumn{1}{|c|}{ Rentangan Nilai } & Kualifikasi \\
\hline$M_{i}+1,5 S_{i} \leq x$ & Sangat Tinggi \\
\hline$M_{i}+0,5 S_{i} \leq x<M_{i}+1,5 S_{i}$ & Tinggi \\
\hline$M_{i}-0,5 S_{i} \leq x<M_{i}+0,5 S_{i}$ & Sedang \\
\hline$M_{i}-1,5 S_{i} \leq x<M_{i}-0,5 S_{i}$ & Rendah \\
\hline$x<M_{i}-1,5 S_{i}$ & Sangat Rendah \\
\hline
\end{tabular}

$M_{i}=1 / 2$ (skor tertinggi ideal + skor terendah ideal)

$S_{i}=1 / 6$ (skor tertinggi ideal - skor terendah ideal)

Respons mahasiswa digali menggunakan kuesioner dengan skala Likert 5 (nilai dari 1 sampai 5) yang dianalisis secara deskriptif. Konversi tingkat respons mahasiswa dapat dilihat pada tabel 3 berikut ini:
Tabel 3. Tabel Konversi Kualifikasi Respons Mahasiswa

\begin{tabular}{|l|c|}
\hline \multicolumn{1}{|c|}{ Rentangan Nilai } & $\begin{array}{c}\text { Kategori } \\
\text { Respons }\end{array}$ \\
\hline$M_{i}+1,5 S_{i} \leq x$ & Sangat Positif \\
\hline$M_{i}+0,5 S_{i} \leq x<M_{i}+1,5 S_{i}$ & Positif \\
\hline$M_{i}-0,5 S_{i} \leq x<M_{i}+0,5 S_{i}$ & Ragu-ragu \\
\hline$M_{i}-1,5 S_{i} \leq x<M_{i}-0,5 S_{i}$ & Negatif \\
\hline$X<M_{i}-1,5 S_{i}$ & Sangat Negatif \\
\hline
\end{tabular}

$M_{i}=1 / 2($ skor tertinggi ideal + skor terendah ideal)

$S_{i}=1 / 6$ (skor tertinggi ideal - skor terendah ideal)

\section{HASIL DAN PEMBAHASAN}

Motivasi belajar mahasiswa Jurusan Pendidikan Teknik Informatika Undiksha Singaraja dalam perkuliahan Matematika Diskrit diukur setelah perkuliahan dengan penggunaan Media Simulasi binary tree berbasis CAI. Angket motivasi belajar Matematika Diskrit untuk mahasiswa terdiri dari 36 butir pernyataan yang diukur dengan skala likert 1-5 sehingga skor tertinggi ideal dan skor terendah ideal masing-masing adalah 180 dan 36. Berdasarkan hasil perhitungan $M_{i}$ dan $S_{i}$ serta klasifikasi tingkat motivasi yang terbentuk maka dapat disimpulkan bahwa tingkat motivasi mahasiswa terhadap penggunaan Media Simulasi Binary Tree Berbasis CAI pada pembelajaran Matematika Diskrit adalah Tinggi, hal ini terlihat dari rata-rata respon yang diperoleh dari 30 orang mahasiswa yang mengisi kuesioner yakni sebesar 121 .

Respons mahasiswa diukur setelah perkuliahan menggunakan Media Simulasi Binary tree berbasis CAI. Angket respons untuk mahasiswa terdiri dari 15 butir pernyataan yang diukur dengan skala likert 1-5 sehingga skor tertinggi ideal dan skor terendah ideal masing-masing adalah 75 dan 15. Dari hasil perhitungan Mi dan SDi yang diperoleh, selanjutnya disusun klasifikasi tingkat respon mahasiswa terhadap Penggunaan Media Simulasi Binary Tree Berbasis CAI pada 
Pembelajaran Matematika Diskrit. Berdasarkan klasifikasi tingkat respon maka dapat disimpulkan bahwa tingkat respon mahasiswa terhadap penggunaan Media Simulasi Binary Tree Berbasis CAI pada pembelajaran Matematika Diskrit adalah positif, hal ini terlihat dari rata-rata respon yang diperoleh dari 30 orang mahasiswa yang mengisi kuesioner yakni sebesar 51.27.

Selanjutnya Tingkat penguasaan konsep yang ditunjukkan melalui hasil belajar matematika diskrit diperoleh melalui 2 kali tugas, satu kali quis dan satu kali ujian. Data nilai tugas, quis dan ujian kemudian dikalikan dengan bobot masingmasing (tugas bobotnya 1, quis bobotnya 2 dan ujian bobotnya 4) yang kemudian dirataratakan untuk masing-masing kelas eksperimen dan kontrol (Tanpa Menggunakan Media Simulasi Binary Tree Berbasis CAl).

Salah satu persyaratan yang harus dipenuhi dalam menggunakan uji-t, adalah bahwa varians dalam kelompok harus homogen. Untuk melakukan uji persyarata serta pengolahan data dapat dilakukan dengan menggunakan perangkat lunak SPSS, diperoleh hasil seperti tabel 4.

Tabel 4. Hasil Pengolahan Data Uji-t dengan Perangkat Lunak SPSS

\begin{tabular}{|ll|r|r|r|c|}
\hline & & & & \\
\hline & Kelas & $\mathrm{N}$ & Mean & Std. Dev iation & $\begin{array}{c}\text { Std. Error } \\
\text { Mean }\end{array}$ \\
\hline Nilai & eksperimen & 30 & 84.3667 & 7.72137 & 1.40972 \\
& kontrol & 30 & 70.4667 & 6.16851 & 1.12621 \\
\hline
\end{tabular}

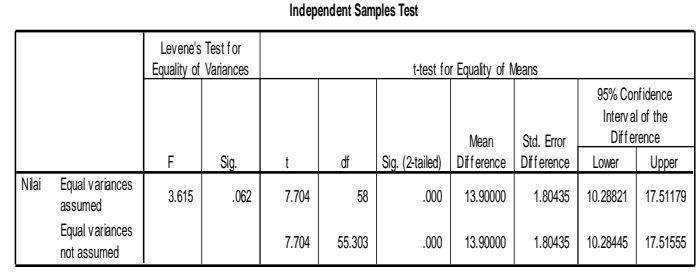

Ada dua tahapan analisis yaitu:

a. Dengan Levene's test, yaitu untuk menguji apakah varians populasi kedua sampel tersebut homogen atau tidak b. Dengan t-test, dan berdasarkan hasil analisis homogenitas sampel diatas maka diambil suatu kesimpulan untuk signifikansi perbedaan rata-rata kedua kelas.

Hipotesis untuk uji homogenitas sampel adalah sebagai berikut :

$\mathrm{H}_{0}$ : Kedua varians populasi adalah homogen

$\mathrm{H}_{1}$ : Kedua varians populasi adalah tidak homogen

Dasar pengambilan keputusan yaitu:

- Jika probabilitas >0,05 maka $\mathrm{H}_{0}$ diterima

- Jika probabilitas $<0,05$ maka $\mathrm{H}_{0}$ ditolak

Dari tabel 4 bagian Independent Sampel Test terlihat bahwa $\mathrm{F}$ hitung untuk nilai dengan diasumsikan kedua varians sama atau menggunakan pooled varians $t$ test adalah 3.615 dengan probabilitas 0,062 . Karena probabilitas $>0,05$ maka $\mathrm{H}_{0}$ diterima yaitu kedua varians populasi adalah identik atau Homogen. Selanjutnya masih dengan memperhatikan tabel 5 bagian Independent Sampel Test, uji-t diperoleh 7.704 dengan nilai probabilitasnya $0.000<0.05$ berarti keputusannya adalah $\mathrm{H}_{0}$ ditolak atau $\mathrm{H}_{1}$ diterima yang artinya Terdapat perbedaan hasil belajar antara mahasiswa yang dibelajarkan menggunakan Media Simulasi binary tree berbasis $C A /$ dengan mahasiswa yang dibelajarkan tanpa menggunakan Media Simulasi binary tree berbasis CAI sebagai alat bantu interaksi dalam pembelajaran Matematika Diskrit.

Dari Hasil yang telah diuraikan diatas, ini menunjukkan bahwa daya tarik pembelajaran Matematika Diskrit dengan menggunakan simulasi binary tree berbasis CAl tercermin dari respon positif yang diberikan mahasiswa dengan rata-rata 51.27. Selanjutnya motivasi belajar mahasiswa dengan digunakannya simulasi binary tree berbasis CAI masuk dalam kategori tinggi. Perkuliahan matematika diskrit yang sebelumnya dirasa membosankan, sulit dan masih begitu 
abstrak setelah disimulasikan menjadi lebih konkrit dan perkuliahan menjadi lebih menyenangkan dan menumbuhkan rasa pecaya diri mahasiswa dengan lebih bersemangat untuk mengikuti perkuliahan matematika diskrit.

Tujuan utama dari pengembangan simulasi berbasis CAI adalah untuk meningkatkan penguasaan materi yang dilihat dari prestasi belajar perkuliahan matematika diskrit, juga tercapai. Hal ini dapat dilihat dari hasil eksperimen dari dua kelas dimana satu kelas dalam proses pembelajaran matematika diskrit diberikan treatment menggunakan simulasi binary tree berbasis CAl sedangkan kelas lainnya (kelas kontrol) menggunakan pembelajaran ekspositori (konvensional/tanpa simulasi). Dari eksperimen tersebut diperoleh hasil bahwa rata-rata hasil belajar kelas eksperimen lebih tinggi yaitu 84.37 dengan variansi kelas 59.62 dibandingkan rata-rata hasil belajar kelas kontrol yaitu 70.47 dengan variansi kelas 38.05. Hasil ini diperkuat lagi setelah dilakukan uji $t$ (student) yang memberikan hasil bahwa Terdapat perbedaan yang signifikan antara hasil belajar mahasiswa yang dibelajarkan menggunakan Media Simulasi binary tree berbasis CAl dengan mahasiswa yang dibelajarkan tanpa menggunakan Media Simulasi binary tree berbasis $C A /$ sebagai alat bantu interaksi dalam pembelajaran Matematika Diskrit. Hal ini menunjukkan bahwa simulasi binary tree berbasis CAI merupakan media yang efektif digunakan untuk meningkatkan penguasaan konsep mahasiswa dalam perkuliahan matematika diskrit di jurusan Pendidikan Teknik Informatika Undiksha Singaraja.

\section{SIMPULAN DAN SARAN}

Dari hasil penelitian dan pembahasan dapat disimpulkan bahwa Terdapat perbedaan yang signifikan antara hasil belajar mahasiswa yang dibelajarkan menggunakan Media Simulasi binary tree berbasis CAl dengan mahasiswa yang dibelajarkan tanpa menggunakan Media Simulasi binary tree berbasis CAl, motivasi mahasiswa setelah dibelajarkan dengan menggunakan media adalah tinggi dan respon yang ditunjukkan adalah positif. Hal ini menunjukkan bahwa simulasi binary tree berbasis CAI merupakan media yang efektif digunakan untuk meningkatkan penguasaan konsep mahasiswa dalam perkuliahan matematika diskrit di jurusan Pendidikan Teknik Informatika Undiksha Singaraja.

Saran untuk penelitian selanjutnya adalah perlu dikembangkan lebih banyak lagi media-media pembelajaran berbasis model dan simulasi untuk membantu mahasiswa yang memiliki kemampuan abstraksi yang kurang dalam materi-materi perkuliahan yang cukup abstrak terutama di bidang ilmu informatika. Pemanfaatan ICT dalam proses pembelajaran hendaknya tetap dilaksanakan dalam kerangka tujuan pembelajaran yang sesuai dengan indikator pencapaian, dengan tidak menimbulkan kondisi pembelajaran yang cenderung dianggap seperti bermain dengan media itu sendiri.

\section{DAFTAR PUSTAKA}

Pendidikan Teknik Informatika,
Undiksha Singaraja , 2010, Arsip Nilai Akhir (DPNA)
Jurusan Pendidikan TI tahun 2008 s/d 2010

De La Cuetara, R. A. \& Lamba, R. S., 1995, "Software to Interface the Student, the Lab Equipment, the Teacher, and the Computer" Journal of Chemical Education, 72, 607- 608

F. Fraij. 2010, "The Impact of Feedback in Computer-Aided Instruction",. International Journal of Soft Computing 5 (2): 67-71, 2010, ISSN: 1816-9503 Medwell. Journals, http:// docsdrive.com/pdfs/medwelliournals/ii scomp/2010/67-71.pdf, diunduh tanggal 25 februari 2011

Jurnal Pendidikan Indonesia | 171 
Gifford, B. R., 1993. "The Future of Technology in Education", Business Week, 3345, Special Advertising Section,

Malone, K., \& Reiland, B., 1995. "Exploring Newton's Third Law", The Physics Teacher, 33, 10-411,

Matray, P., \& Proulx, S, 1995."Integrating Computer/Multimedia Technology in a High School Biology Curriculum", The American Biology Teacher, 57, 511520

Mustafa Bakaç, Ashhan Kartal Taşoğlu, Turgay Akbay. 2011, "The Effect of Computer Assisted Instruction with Simulation in Science and Physics Activities on the Success of Student: Electric Current" , Eurasian Journal. Phys. Chem. Educ., Jan (Special Issue):34-42,. journal homepage: http://www.eurasianjournals.com/index .php/ejpce diunduh tanggal 25 februari 2011

Mumford, G., 1992, "Science in an Imaginary Sky”, Sky \& Telescope, 83(2), 146-148

Peck, K. L., \& Dorricott, D., 1994, "Why Use Technology?", Leadership, 51(7), 11-18,

Redish, E. F., \& Wilson, J. M., 1993, "Student programming in the introductory physics course: M.U.P.P.E.T", , The American Journal of Physics, 61, 222-231

Santyasa I Wayan, 2009. "Metode Penelitian Tindakan Kelas, Pengembangan, Korelasional, Kausal Komparatif, dan Eksperimen", Lembaga Penelitian Universitas Pendidikan Ganesha, Singaraja..

Saroso, 2009 "Mengenal Media Pembelajaran", http://eduarticles.com,. Tanggal akses: 7 Februari 2009

Sudrajat Akhmad. 2009, "Media Pembelajaran", http://akhmadsudrajat. wordpress.com., diunduh tanggal : 20 Februari 2011
Sujanem Rai, 2009, "Penerapan Pembelajaran Inovatif Berbasis TIK", Makalah Seminar, Undiksha

Smith Adrian, Fosse Richard, Dewhurst David, and Smith Karina, 1997 "The Role of Computational Models in Animal Research Educational Simulation Models in the Biomedical Sciences", ILAR Journal, V38(2),

Winkel W. S. 1996,"Psikologi Pengajaran", Edisi Revisi, PT. Grasindo, Jakarta.

Windu Antara, 2011"Simulation based CAI of list data structure for the learning process of design and analysis of algorithm", Prosiding Seminar Internasional Teknologi Informasi dan Pendidikan, Bridging ICT and Education, ISSN 1907-3739, Fakultas Teknik Universitas Negeri Padang. 